\title{
Drying of Okra by Different Drying Methods: Comparison of Drying time, Product Color Quality, Energy Consumption and Rehydration
}

\author{
By Osman Ismail , Azmi Seyhun Kipcak ${ }^{\dagger}$ \& Ibrahim Doymaz
}

In this study, okra was dried and modelled with using five different drying methods exist in literature. In the methods of vacuum and hot air drying, the drying temperature of $50^{\circ} \mathrm{C}$ was selected, while the powers of microwave and infrared were set as $90 \mathrm{~W}$ and $83 \mathrm{~W}$, respectively. The results were evaluated in terms of drying time, product color quality, energy consumption and rehydration. The minimum drying time was obtained by microwave drying method. Also, the energy efficiency increased with the microwave drying method. In terms of color criteria the best value was obtained by the hot-air drying method. Rehydration content of dried okra samples with hot air was higher than that of other drying methods. From the results of this study, the most efficient drying methods were determined as microwave and hot-air drying.

Keywords: Color, Drying Methods, Rehydration, Specific Energy Consumption.

\section{Introduction}

Okra (Abelmoschus esculentus L. Moench), which belongs to the family Malvaceae is an annual vegetable crop growing 3 to 6 feet tall (Pendre et al. 2012, Afolabi and Agarry 2014). According to FAO data for $2015^{1}$, okra production all over the world was about 1104407 hectares. The major producer countries include India (530790 hectares), Nigeria (385000 hectares), Ivory Coast (50000 hectares), Cameroon (23998 hectares) and Sudan (22114 hectares). Turkey has the tenth place in the production of okra with 6099 hectares.

Among the several drying methods, in hot air drying method, which has been used widely, the lower energy efficiency and long drying times are the disadvantages (El-Mesery and Mwithiga 2012, Feng and Tang 1998, Pan et al. 2008). Open-sun drying is the most common method of crop drying in developing countries. Despite several disadvantages, open-sun drying is still used in many places throughout the world where plenty of solar radiation is available. Also it is renewable, cheap and eco-friendly. The only problem of drying open-sun is drying time is slow according to the other drying methods (Tunde-Akintunde 2011).

In recent years, attempts have been made to shorten the drying period to improve the energy efficiency of the drying process and the quality of the dried

\footnotetext{
*Assistant Professor, Yildiz Technical University, Turkey.

${ }^{\dagger}$ Associate Professor, Yildiz Technical University, Turkey.

${ }^{\ddagger}$ Associate Professor, Yildiz Technical University, Turkey.

${ }^{1}$ FAO Statistical Database (2015). Available from: http://faostat.fao.org/.
} 
products. The quality of the dried products could be improved by decreasing the drying temperature or the drying time. Therefore, instead of open-sun drying, microwave, infrared, oven and vacuum drying is widely preferred (Başlar et al. 2014). Infrared drying method has so many advantages in comparison with hot air drying, because the equipment can be compact with easily controllable parameters (Sakai and Mao 2006). In microwave drying, short drying time that leads to lower energy consumption and better quality of the dried food is the most advantage among the other drying methods (İsmail and Kocabay 2016).

The increase in the population and energy needs are two important factors that trigger each other. Energy production is with increasing need in developing countries, directly proportional to the development level of the country. The food industry has the energy-dependent processes required for ensuring the freshness of foods and reliability. Heat treatment and drying are the most common processes, which use significant amount of energy for the preservation of foods. In the food industry $29 \%$ of the total energy used in the heat treatment processes and $16 \%$ is used for cooling and freezing processes. In today, various criteria are evaluated for the drying performances; such as moisture absorption rate, energy consumption and specific energy consumption (Okos et al. 1998). For this relation to decrease the energy costs is the main focus for the dehydration processes. Existing studies in the literature is very much about the drying methods of food products. Also these methods are known as the energyconsuming food preservation methods, hence to decrease the energy cost on these methods is worth of a study.

There are several factors influencing the quality parameters of dried product. Some chemical and biochemical reactions such as browning reactions and lipid oxidation might alter the final color (Okos et al. 2007). Drying conditions and physicochemical changes that occur during drying and rehydration processes seem to affect the quality properties of the rehydrated products (Rudra et al. 2008).

Processed and value added products are gaining importance in the worldwide markets. Dried okra is one of these. According to TUIK data for 2015, okra production all over the Turkey was about 31,898 tonnes. Okra is mainly exported in the form of fresh okra, dehydrated okra, canned okra and okra pickle. Dehydrated okra is considered as a potential product in world trade. In European countries, the demand for fresh and dried okra is very high. For this reason, the exports of okra play an important role in the Turkish economy. The various kinds of drying methods followed for dehydration of okra such as convective air drying, open sun drying, vacuum drying, microwave drying and infrared drying are reviewed here. These techniques are mainly used for preservation and value addition of okra. There are many studies on okra in the literature. Other studies about okra dried with different drying methods and present works are summarized in Table 1 (Afolabi and Agarry 2014, Wankhade et al. 2012, Doymaz 2011, Kocabay and Ismail 2017, Dadal1 et al. 2007, Doymaz 2005, Shivharea et al. 2010, Gogus and Maskan 1999, Adom et al. 1997, Al-Sulaiman 2011, Ismail and Ibn Idriss 2013, Ajay and Fakayode 2011, Huang and Zhang 2016, Aamir and Boonsupthip 2017). 
Table 1. Studies on the Drying of Okra in the Literature

\begin{tabular}{|c|c|c|c|c|c|}
\hline $\begin{array}{l}\text { Drying } \\
\text { method }\end{array}$ & Pretreatment & $\begin{array}{c}\text { Drying } \\
\text { conditions } \\
\left(\text { Hot air }\left({ }^{\circ} \mathbf{C}\right)\right. \\
\text { Microwave } \\
(W) \\
\end{array}$ & $\begin{array}{c}\text { Air } \\
\text { velocity } \\
(\mathbf{m} / \mathbf{s})\end{array}$ & $\begin{array}{l}\text { Drying } \\
\text { time } \\
\text { min }\end{array}$ & Ref. \\
\hline Hot air drying & \multirow{3}{*}{ Natural } & $50,60,70$ & - & $600-780$ & $\begin{array}{l}\text { Afolabi and } \\
\text { Agarry } 2014\end{array}$ \\
\hline Sun drying & & - & - & 7200 & $\begin{array}{l}\text { Afolabi and } \\
\text { Agarry } 2014\end{array}$ \\
\hline Solar drying & & - & - & 4320 & $\begin{array}{l}\text { Afolabi and } \\
\text { Agarry } 2014\end{array}$ \\
\hline Hot air drying & \multirow{3}{*}{ Natural } & 40 & 1 & 960 & \multirow{3}{*}{$\begin{array}{l}\text { Wankhade } \\
\text { et al. } 2012\end{array}$} \\
\hline Sun drying & & - & - & 1380 & \\
\hline Solar drying & & - & - & 900 & \\
\hline Sun drying & Natural & - & - & 6000 & $\begin{array}{c}\text { Doymaz } \\
2011\end{array}$ \\
\hline \multirow{3}{*}{ Sun drying } & Natural & - & - & 1980 & \multirow{3}{*}{$\begin{array}{c}\text { Kocabay } \\
\text { and Ismail } \\
2017\end{array}$} \\
\hline & Blanched & - & - & 1080 & \\
\hline & Salted & - & - & 1320 & \\
\hline $\begin{array}{c}\text { Microwave } \\
\text { drying }\end{array}$ & Natural & $\begin{array}{c}180,360,540 \\
720,900 \\
\end{array}$ & - & $\begin{array}{c}50,37, \\
23,20,15 \\
\end{array}$ & $\begin{array}{c}\text { Dadali et al. } \\
2007\end{array}$ \\
\hline Hot air drying & Natural & $50,60,70$ & 1 & $\begin{array}{c}960,630, \\
480\end{array}$ & $\begin{array}{c}\text { Doymaz } \\
2005 \\
\end{array}$ \\
\hline Hot air drying & $\begin{array}{c}\mathrm{NaCl}- \\
\text { blanched }\end{array}$ & $40,55,70$ & - & $\begin{array}{c}780,540, \\
300\end{array}$ & $\begin{array}{l}\text { Shivharea et } \\
\text { al. } 2010\end{array}$ \\
\hline Hot air drying & Natural & $60,70,80$ & 1.2 & $\begin{array}{l}860,570 \\
440\end{array}$ & $\begin{array}{c}\text { Gogus and } \\
\text { Maskan } \\
1999\end{array}$ \\
\hline $\begin{array}{l}\text { Solar tent } \\
\text { dryer }\end{array}$ & Natural & $30-60$ & $0-0.2$ & 2880 & $\begin{array}{c}\text { Adom et al. } \\
1997\end{array}$ \\
\hline $\begin{array}{l}\text { Microwave } \\
\text { drying }\end{array}$ & Natural & $\begin{array}{l}75,150,300 \\
500,700,900\end{array}$ & - & $\begin{array}{l}19,18 \\
17,16 \\
15,13\end{array}$ & $\begin{array}{l}\text { Al-Sulaiman } \\
\quad 2011\end{array}$ \\
\hline Solar drying & Natural & - & - & 1620 & $\begin{array}{c}\text { Ismail and } \\
\text { Ibn Idriss } \\
2013 \\
\end{array}$ \\
\hline Hot air drying & Natural & $50,60,70$ & 14.6 & $\begin{array}{c}580,560 \\
540\end{array}$ & $\begin{array}{c}\text { Ajay and } \\
\text { Fakayode } \\
2011\end{array}$ \\
\hline $\begin{array}{c}\text { Vacuum } \\
\text { freeze drying }\end{array}$ & \multirow{3}{*}{ Natural } & $\begin{array}{c}100 \mathrm{~Pa} \\
45,-38^{\circ} \mathrm{C} \\
\end{array}$ & - & 720 & \multirow{3}{*}{$\begin{array}{l}\text { Huang and } \\
\text { Zhang } 2016\end{array}$} \\
\hline $\begin{array}{l}\text { Microwave } \\
\text { vacuum } \\
\text { drying } \\
\end{array}$ & & 500 & - & 110 & \\
\hline $\begin{array}{l}\text { Pulse-spouted } \\
\text { microwave } \\
\text { vacuum } \\
\text { drying }\end{array}$ & & 500 & - & 95 & \\
\hline $\begin{array}{l}\text { Microwave } \\
\text { drying }\end{array}$ & Natural & $440,618,800$ & - & $7,5,4$ & $\begin{array}{c}\text { Aamir and } \\
\text { Boonsupthip } \\
2017\end{array}$ \\
\hline
\end{tabular}


As it is seen from the literature, at the sun drying the drying times were very different due to the daily temperature and solar radiation $\left(\mathrm{W} / \mathrm{m}^{2}\right)$ in summer months (June, July and August), relative humidity, wind speed and okra thickness. The differences of the hot-air drying times are due to the relative humidity and airflow. There is no considerable difference in microwave drying.

Hot air drying and sun drying are traditional drying technologies widely used in the drying of agricultural products for a long time, but usually recognized as time-consuming or producing lower-quality products. Microwave drying is a rather effective drying technology that has advantages over traditional drying technologies. According to the studies given in the literature, there is no study about the infrared and vacuum oven drying of okra. In the sun drying of okra the ambient temperature less than $50^{\circ} \mathrm{C}$, so in this study considering the mentioned temperature $50^{\circ} \mathrm{C}$ is taken as the reference temperature. Hence, reduced power levels both on microwave and infrared method is used. Based on the literature, five different drying methods have been applied to the drying of the okra samples. Drying time, product color, energy consumption rehydration are examined and compared.

\section{Methodology}

\section{Samples}

Fresh okra (Hibiscus esculentus L.) samples, which have approximately the same length and diameter were collected from Thrace region of Turkey. The selected okra samples were cleaned with tap water to make samples free from dust and foreign materials and stored at $4.0 \pm 0.5^{\circ} \mathrm{C}$ in the refrigerator for about one day for the moisture equilibrium. Then, okras were removed from the refrigerator and allowed to reach to the ambient temperature. The stalk and tapered head of the cleaned samples were cut off to form a cylinder-like shape with an approximate length and weight of $50 \pm 0.3 \mathrm{~mm}$ and $4 \pm 0.3 \mathrm{~g}$, respectively. Average diameter of okra samples was measured as $1.1 \pm 0.2 \mathrm{~cm}$. Dry matter and moisture contents of the fresh samples were determined prior to drying process. To determine the initial moisture content, four identical experiments were conducted. In these experiments approximately $15 \pm 0.2 \mathrm{~g}$ samples were dried in an oven (Memmert UM-400, Germany) at $105^{\circ} \mathrm{C}$ for 24 $\mathrm{h}$ (AOAC 1990). The average initial moisture content of okra was found as 84 $\%$ wet base (w.b.).

\section{Drying Equipments and Drying Procedures}

After the drying procedures explained below, all of the dried samples were packed in low density polyethylene bags. 


\section{Open-Sun Drying}

Open-sun drying experiments were carried out during August 2016 (08.00 AM - 20.00 PM) in Turkey. The okra samples, about $30 \pm 0.2 \mathrm{~g}$ were distributed uniformly in a single layer in the sample tray, and exposed to sunlight for $12 \mathrm{~h}$ daily. Moisture loss and temperature of the ambient air were measured at 1 hour intervals during drying by a portable digital balance (Alfais, I2000-1, which has 0$300 \mathrm{~g}$ measurement range with an accuracy of $\pm 0.1 \mathrm{~g}$ ). When the drying time took more than $12 \mathrm{~h}$, the samples during the night were packed for reducing the effect on increase in moisture content. During the drying experiments, the temperature of ambient air ranged from 32 to $45^{\circ} \mathrm{C}$. The highest air temperature was reached between 10:30 AM and 14:30 PM. Drying was continued until the samples reached the desired moisture level of approximately $0.092 \mathrm{~g}$ water/g dry matter.

\section{Infrared Drying}

Drying experiments were carried out in a moisture analyzer with one 250 W halogen lamp (Snijders Moisture Balance, Snijders b.v., Tilburg, Holland). In the infrared drying process, samples should be separated evenly and homogeneously over the entire pan. The power level was set in control unit of equipment. The drying experiment was performed at infrared power level to 83 W. The samples of okra (approximately $30 \pm 0.2 \mathrm{~g}$ ) were removed of dryer at a time interval of $15 \mathrm{~min}$ during the drying process, and their weights were measured with a digital balance (Precisa, model XB220A, Precisa Instruments AG, Dietikon, Switzerland) with an accuracy of $0.001 \mathrm{~g}$. The temperature is not measured. Drying was finished when the moisture content of the samples was approximately $0.084 \mathrm{~g}$ water / $\mathrm{g}$ dry matter.

\section{$\underline{\text { Microwave Drying }}$}

Drying experiments were carried out in a Robert Bosch Hausgerate $\mathrm{GmbH}$ (Germany) model microwave oven which has a maximum output of $800 \mathrm{~W}$ working at $2450 \mathrm{MHz}$. The microwave oven has the capability of operating at different microwave stages, from $90 \mathrm{~W}$ to $800 \mathrm{~W}$. The area on which microwave drying was performed was $530 \times 500 \times 322 \mathrm{~mm}$ in size and consisted of a rotating glass plate $300 \mathrm{~mm}$ in diameter at the base of the oven. The adjustment of microwave output power and processing time was done with the aid of a digital control facility located on the microwave oven. Drying experiment was carried out at a microwave power level of $90 \mathrm{~W}$. During drying experiment $30 \pm 0.2 \mathrm{~g}$ okra arranged as a thin layer on the rotatable plate fitted inside the microwave oven cabinet. The rotating glass plate was removed from the oven every 2 min during the drying period and moisture loss determined by weighing the plate using a digital balance. The temperature is not measured. Microwave drying continued till the moisture reduces to $0.112 \mathrm{~g}$ water/g dry matter of the initial moisture content. 


\section{Vacuum Oven Drying}

Vacuum oven drying was performed in a laboratory type vacuum oven (Nuve EV 018, Turkey) with technical features of $\sim 220 \mathrm{~V}, 50 \mathrm{~Hz}, 3.5 \mathrm{~A}$ and 800 $\mathrm{W}$. The temperature of the vacuum oven has a sensitivity of $1^{\circ} \mathrm{C}$, with a max temperature of $250^{\circ} \mathrm{C}$. The area on which vacuum drying oven was performed was

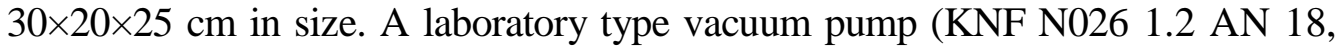
Turkey) was used in the vacuum drying operation. Its operating conditions were $220 \mathrm{~V}, 50 \mathrm{~Hz}$ and $0.85 \mathrm{~A}$. The adjustment of vacuum value and processing temperature was done with the aid of a digital control facility located on the vacuum drying oven. The drying experiment was carried out using okra samples of weight of about $30 \pm 0.2 \mathrm{~g}$ and at one vacuum oven dryer at a constant temperature of $50^{\circ} \mathrm{C}$ and pressure of $0.1 \mathrm{kPa}$. Moisture loss in the okra samples was measured at 30 min intervals. Drying was finished when the moisture content of the samples was approximately $0.087 \mathrm{~g}$ water / g dry matter.

\section{$\underline{\text { Hot-Air Drying }}$}

Drying experiments were performed in a cabinet type dryer (APV \& PASILAC Limited of Carlisle, Cumbria, UK). It was constructed from stainless steel sheets formed as a rectangular tunnel of dimensions $0.54 \times 1.4 \times 1.02 \mathrm{~m}$. The dryer consisted of a centrifugal fan to supply the airflow, an electrical heater, an air filter and a proportional temperature controller. The dryer is operated at dry bulb temperatures between $0-200^{\circ} \mathrm{C}$. The desired drying air temperature was attained by electrical resistance and controlled by the heating control unit. The velocity of air passing through the system was measured via a $0.4-30 \mathrm{~m} / \mathrm{s}$ range anemometer (model AM-4201, Lutron Electronic, Taipei, Taiwan). The airflow was measured directly in the drying chamber. The samples are dried in the perforated basket 30 $\mathrm{cm}$ square and $11 \mathrm{~cm}$ high, and moisture loss is recorded during drying by a specially developed weighing unit. This weighing unit consists of a balance $(20 \mathrm{~kg}$ capacity), hanger rod, digital indicator and load cell (Revere Transducers Europe, Holland). The okra samples, about $50 \pm 0.3 \mathrm{~g}$ were distributed uniformly in a single layer in the sample tray, and then dried in hot air dryer_at $50^{\circ} \mathrm{C}$ air temperature and a constant air velocity of $1 \mathrm{~m} / \mathrm{s}$. Moisture loss in the okra samples was measured at 30 min intervals. Drying was finished when the moisture content of the samples was approximately $0.085 \mathrm{~g}$ water/g dry matter.

\section{Color Measurement}

Sample color was measured before (fresh okra) and after drying methods using a Chromameter CR-400 (Minolta, Japan). $L, a$ and $b$ values were measured to describe three dimensional color space and interpreted as follows: $L$ is the brightness/lightness or whiteness ranging from no reflection for black $(L=0)$ to perfect diffuse reflection for white $(L=100)$. The value $a$, is the redness ranging from negative values for green to positive values for red. The value $b$ is the 
yellowness ranging from negative values for blue to positive values for yellow. The total change in color $(\Delta E)$ of dried samples was calculated as follows (Phoungchandang and Saentaweesuk 2011):

$$
\Delta E=\sqrt{\left(\left(L_{o}-L\right)^{2}+\left(a_{0}-a\right)^{2}+\left(b_{0}-b\right)^{2}\right)}
$$

where $L_{o}, a_{o}$ and $b_{o}$ are the color values of okra samples before drying samples. Fresh okra samples were used as the reference while a higher $\Delta E$ represents a greater colour change from the reference material.

\section{Calculation of Specific Energy Consumption}

The total energy consumption of the drying process was evaluated through the Specific Energy Consumption (SEC). During drying, the electrical energy was consumed. Energy consumption of infrared radiation, microwave, hot-air convection, oven and vacuum oven with together vacuum pump was determined using a digital electric counter (Kaan, Type 111, Turkey) with $0.01 \mathrm{kWh}$ precision. The specific energy consumption which is a measure of the energy needed to evaporate a unit mass of water from the product was calculated using Eq. 2 (Ismail and Kocabay 2016):

$Q_{s}=\frac{Q_{t}}{m_{w}}$

where $Q_{s}$ is the specific energy consumption in $\mathrm{kWh} / \mathrm{kg}$ water, $Q_{t}$ is the consumed energy in $\mathrm{kWh}$, and $m_{w}$ is the mass of vaporized water in $\mathrm{kg}$ water.

\section{Rehydration Experiments}

Rehydration and diffusion are two important parameters in the characterization of the dried foods. Okra samples were rehydrated by immersion in distilled water at controlled room temperature. In other words, five dried okra samples introduced in a plastic mesh basket were immersed during a pre-determined time into water at $25^{\circ} \mathrm{C}$ using glass jar with $300 \mathrm{~mL}$ of water. At every $30 \mathrm{~min}$ intervals, okra samples were removed from water, drained, and weighed. The weights of samples were measured with an electronic digital balance. The weight change was observed at specific intervals until the equilibrium moisture content was reached. The experiments were carried out in duplicate and their average values were reported. The rehydration ratio $\left(R_{R}\right)$ was calculated using Eq. 3: 
$R_{R}=\frac{W_{t}-W_{d r y}}{W_{d r y}}$

where $W_{t}$ and $W_{d r y}$ are the weight of the samples at any time $(\mathrm{g})$ and the dry weight $(\mathrm{g})$, respectively. Also in the rehydration experiments, the data observed were found at $p<0.05$.

\section{Results and Discussion}

Drying Time

The effect of the different drying methods on the drying time of okra is given in Figure 1. From Figure 1 it is seen that the drying times of okra was recorded in the range of $46 \mathrm{~min}$ to $50 \mathrm{~h}$. The maximum drying time of okra was reached by the open-sun drying method with a drying value of $50 \mathrm{~h}$. Like the microwave method in which the experiments were conducted at $90 \mathrm{~W}$ power level, the drying time of the okra samples about 46 minutes. Other drying methods, which were conducted at a temperature of $50^{\circ} \mathrm{C}$, the drying times were found as 13.5, 10 and $9.25 \mathrm{~h}$ for the drying methods of hot-air, vacuum and infrared drying, respectively. The drying times were determined from highest to lowest as; open-sun drying > hot-air drying > vacuum drying > infrared drying $>$ microwave drying.

Figure 1. The Effect of the Drying Methods on the Drying Time of Okra

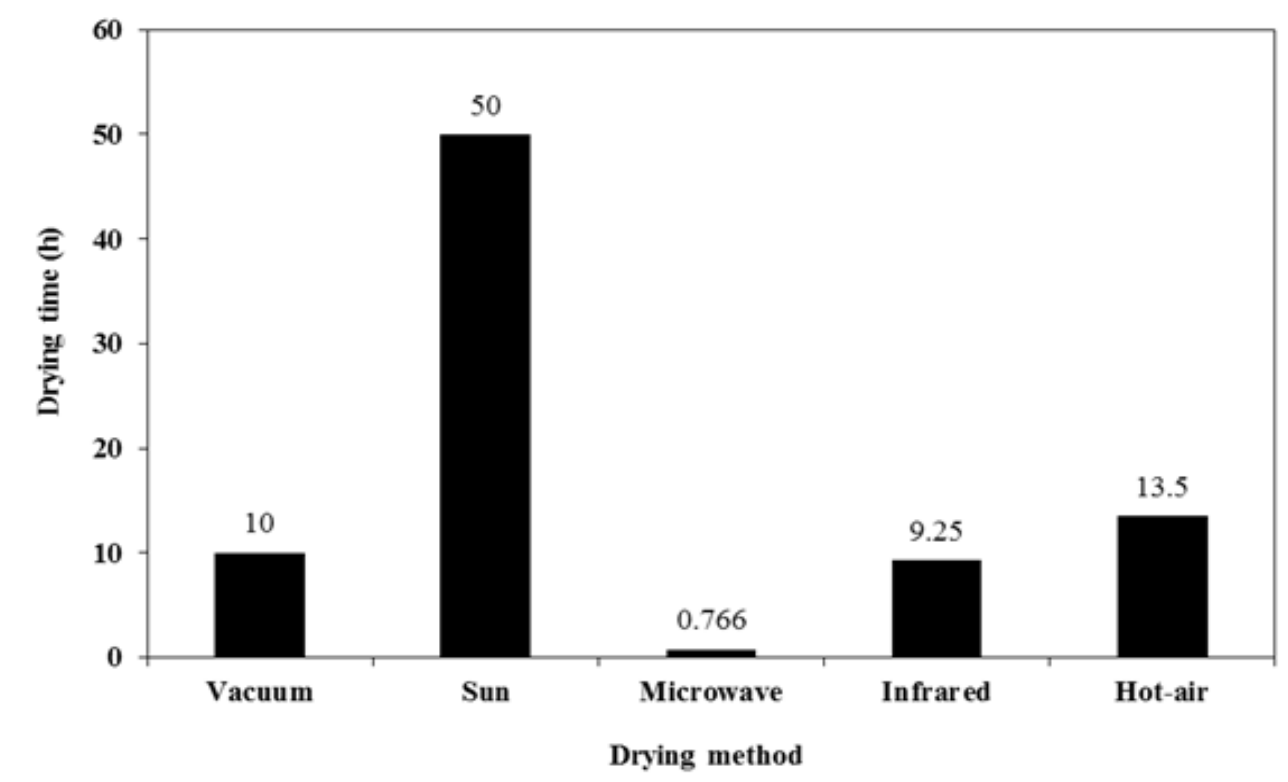




\section{Color Analysis}

Color is one of the most important factors among the food acceptability parameters. Too much color change on the food product adversely affects the food quality, which leads to decrease the marketing sales of the products. In other words, the initial quality parameter assessed by customers is the surface color of the food. The fresh okra samples $L, a$ and $b$ values were measured as $42.69,-3.6$ and 8.34 , respectively. The impact of different drying methods upon the color parameters of the dried okra samples was exhibited in Table 2.

Table 2. Color Analysis Results of Okra

\begin{tabular}{|l|c|c|c|c|c|}
\hline $\begin{array}{l}\text { Drying } \\
\text { methods }\end{array}$ & Samples & $\boldsymbol{L}^{*}$ & $\boldsymbol{a}$ & $\boldsymbol{b}$ & $\boldsymbol{\Delta}$ \\
\cline { 2 - 6 } & Fresh & $\begin{array}{c}42.69 \pm \\
0.99\end{array}$ & $-3.6 \pm 0.84$ & $8.34 \pm 0.54$ & - \\
\hline $\begin{array}{l}\text { Vacuum } \\
\text { oven }\end{array}$ & Dry & $\begin{array}{c}44.71 \pm \\
1.03\end{array}$ & $6.80 \pm 0.78$ & $9.39 \pm 0.68$ & $\begin{array}{c}10.64 \pm \\
1.08\end{array}$ \\
\hline Open-sun & Dry & $\begin{array}{c}51.35 \pm \\
1.26\end{array}$ & $\begin{array}{c}11.38 \pm \\
0.89\end{array}$ & $\begin{array}{c}16.02 \pm \\
0.65\end{array}$ & $\begin{array}{c}18.93 \pm \\
1.34\end{array}$ \\
\hline Microwave & Dry & $\begin{array}{c}50.21 \pm \\
0.59\end{array}$ & $4.85 \pm 0.72$ & $\begin{array}{c}15.79 \pm \\
1.03\end{array}$ & $\begin{array}{c}13.54 \pm \\
0.94\end{array}$ \\
\hline Infrared & Dry & $\begin{array}{c}45.39 \pm \\
1.04\end{array}$ & $5.39 \pm 0.39$ & $\begin{array}{c}14.36 \pm \\
0.74\end{array}$ & $\begin{array}{c}11.15 \pm \\
1.92\end{array}$ \\
\hline Hot-air & Dry & $\begin{array}{c}48.82 \pm \\
1.18\end{array}$ & $3.67 \pm 0.16$ & $9.80 \pm 0.90$ & $9.62 \pm 1.18$ \\
\hline
\end{tabular}

*Values are means \pm SEE.

From the results of Table 2, it is seen that the fresh okra had a lightness value of 42.69. The lightness values of the dried okra samples range from 44.71 to 51.35 , where the all drying methods increased the lightness. The highest lightness value was seen at the method of open-sun drying with a value of 51.35. Then, microwave and hot-air drying methods were followed with the lightness values of 50.21 and 48.82, respectively. From the $a$ and $b$ values results of the dried okras, it is seen that the redness and yellowness of the dried okras were increased with respect to fresh okras.

The total color change $(\Delta E)$ was calculated according to Eq. (1) using the measured $L, a$ and $b$ values. A larger $\Delta E$ value represents a greater change in color. Table 2 also presents the $\Delta E$ of the sample dried at five drying conditions. The color change of the dried okra samples was determined in terms of $\Delta E$, which ranged from 9.62 to 18.93 for different drying methods. The lowest $\Delta E$ value is seen on the hot air drying method with a value of 9.62. Result from here, hot air dried okra showed the least color change compared to the fresh okra sample. Similar results can be seen in the literature (Mana et al. 2012, Cao et al. 2016). Since high lightness $(L)$ and low total color change $(\Delta E)$ value were preferred in the food drying, hot air drying method gave better results for the preservation of the color quality. 


\section{Energy Consumption}

The energy consumption values obtained using vacuum, microwave, infrared and hot-air drying of okras are given in Figure 2. When the four drying methods were compared with respect to energy consumption values, it is seen that the lowest energy consumption occurred in microwave drying method and it is followed by infrared, vacuum and hot-air drying methods. Since the energy value for open-sun drying method is zero, open-sun drying method is not included in Figure 2.

Figure 2. Energy Consumption during the Drying of Okras

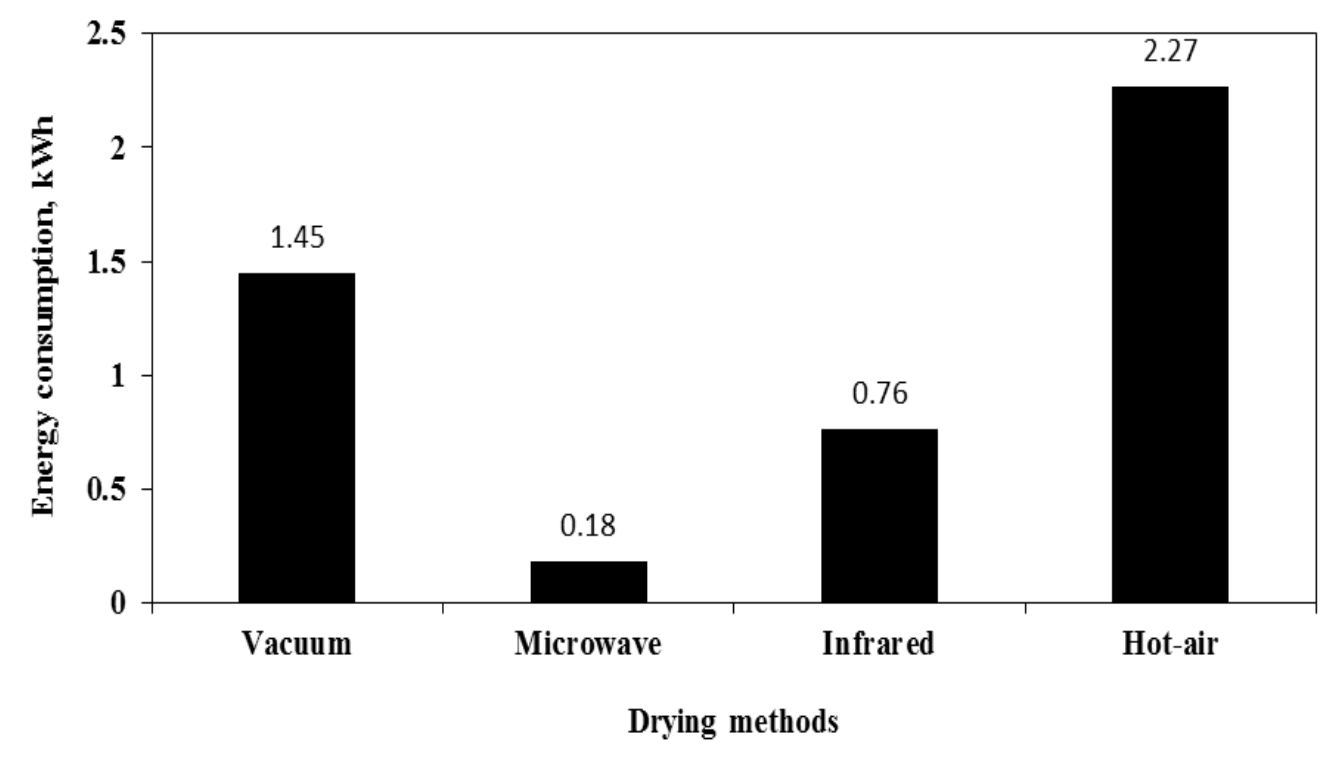

The best result was found as the microwave drying method among all drying methods considering the energy consumption values. Energy consumption of microwave method was found as $0.18 \mathrm{kWh}$. The highest value in all drying methods considering the energy consumption was seen in hot-air drying, with a value of $2.27 \mathrm{kWh}$. Other methods of infrared and vacuum oven drying energy consumption values are found as 0.76 and $1.45 \mathrm{kWh}$, respectively. As a result of this study, the drying processes carried out at low temperature and power levels, leads to a longer drying period and higher energy consumptions. These results are in agreement with the literature (El-Mesery and Mwithiga 2012).

\section{Specific Energy Consumption}

The specific energy consumption was determined, in all of the four drying methods by considering the total energy supplied to dry the okra samples from initial moisture content of about $5.25 \mathrm{~g}$ water / g dry matter to a final moisture content of approximately 0.07-0.12 g water / $g$ dry matter. The specific energy consumption of the drying process under different drying methods were calculated by using Eq. (2) and given in Figure 3. As can be seen from Figure 3 , the minimum energy ( $20.54 \mathrm{kWh} / \mathrm{kg}$ water) is needed for drying of $1 \mathrm{~kg}$ of 
okra samples at microwave drying method. The maximum energy $(69.95 \mathrm{kWh}$ / $\mathrm{kg}$ water) is needed at vacuum oven drying method. Hence microwave drying method is the most suitable method for drying fresh okra samples because of the minimum energy consumption $(20.54 \mathrm{kWh} / \mathrm{kg}$ water) and drying time (46 $\min )$. The results that are found are similar to those reported by researchers for other products (Sharma and Prasad 2006, Motevali et al. 2011).

Figure 3. Specific Energy Consumption for Drying $1 \mathrm{~kg}$ of Wet Product

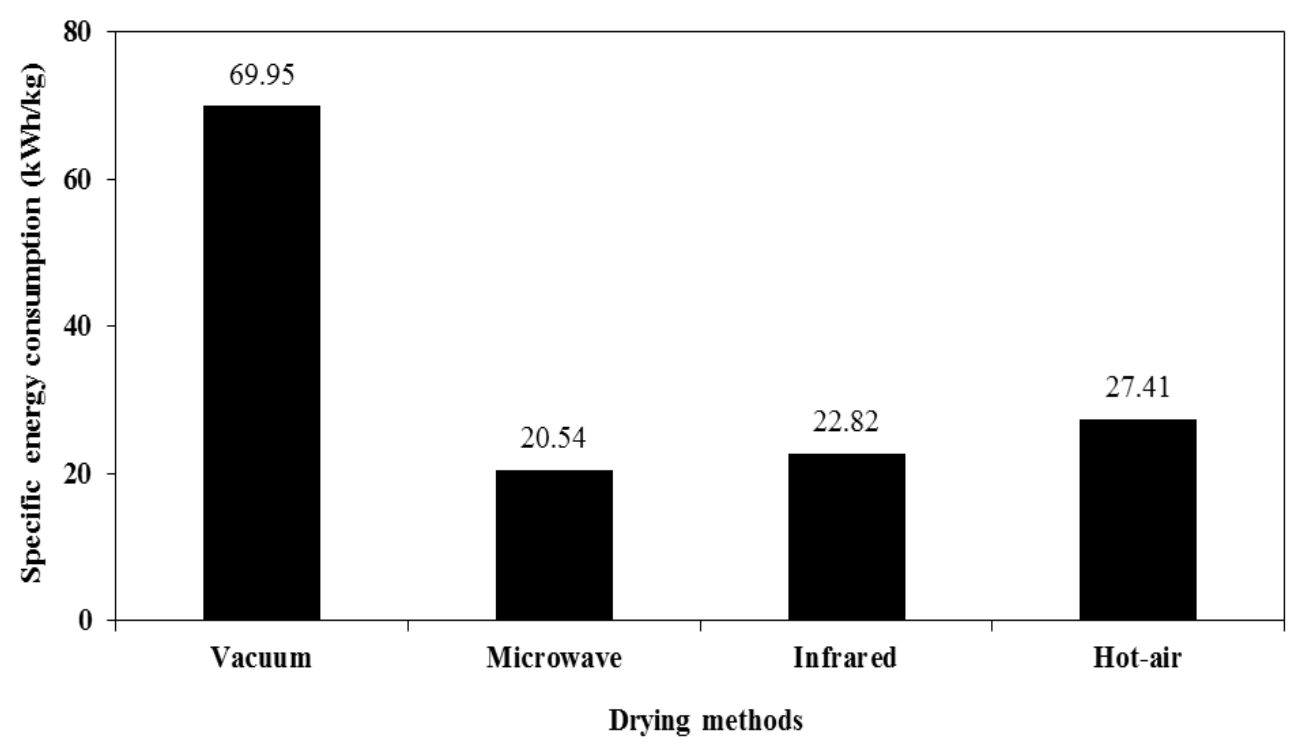

\section{Rehydration}

Rehydration process depends on structural changes in vegetal tissues and cells of food material during drying, which produces shrinkage and collapse and reduces the water absorption capacity, thereby preventing the complete rehydration of the dried product (Krokida and Philippopoulos 2005). Using Eq. (3), the rehydration content $\left(R_{R}\right)$ values are calculated and are shown in Figure 4. Since there are no significance changes after $200 \mathrm{mins}$, rehydration experiments were terminated at 270 mins. As it seen from Figure 4, the rehydration contents ranged from 3.35 to $4.86 \mathrm{~g}_{\text {water }} / \mathrm{g}_{\text {dry matter }}$. The highest rehydration content of $4.86 \mathrm{~g}$ water / $\mathrm{g}$ dry matter was found in hot-air method then followed by open-sun (4.39 $\left.\mathrm{g}_{\text {water }} / \mathrm{g}_{\text {dry matter }}\right)$, infrared 4.29 ( $\left.\mathrm{g}_{\text {water }} / \mathrm{g}_{\text {dry matter }}\right)$, vacuum oven $\left(4.12 \mathrm{~g}_{\text {water }} / \mathrm{g}_{\text {dry matter }}\right)$ and microwave (3.35 $\left.\mathrm{g}_{\text {water }} / \mathrm{g}_{\mathrm{dry} \text { matter }}\right)$ methods. Similar results can be found at the studies of Moreira et al. (2008) and Mana et al. (2012). 
Figure 4. Rehydration Results of Dried Okra Samples

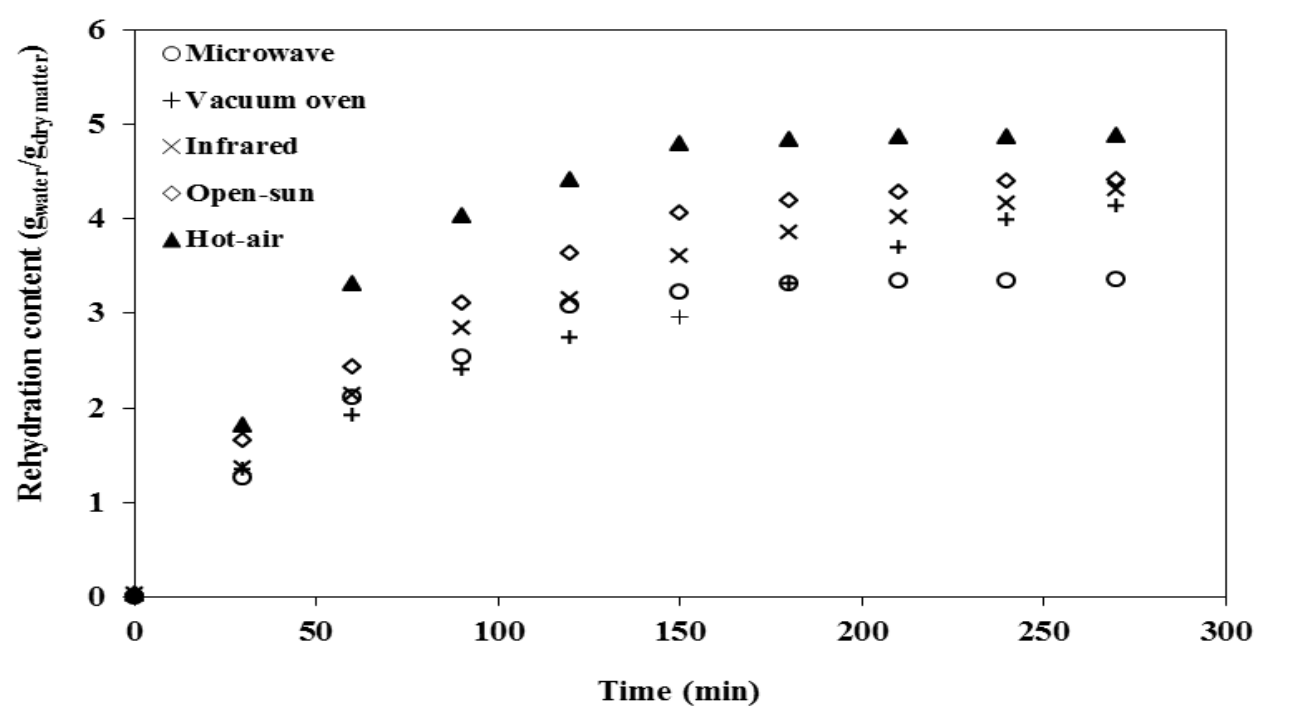

\section{Conclusions}

The growing trend on the amount of quality products and energy costs has motivated researchers to do research using different combinations of drying technologies. Based on the several conducted analyses, the best method for the drying of okra samples was found as the microwave drying method, considering the low drying time (46 min), low energy consumption $(0.18 \mathrm{kWh})$ and low specific energy consumption $(20.54 \mathrm{kWh} / \mathrm{kg}$ water). It can be said that this method can be applied to industry easily and can provide consumers to highquality and uniform products. Highest rehydration contents and lowest total color change (9.62), were obtained in dried okra samples with hot air. Apart from the microwave drying method, hot air drying is also recommended for okra drying in terms of rehydration and total color change.

\section{Nomenclature}

$\begin{array}{ll}L & \text { Lightness } \\ a & \text { Greenness } \\ b & \text { Yellowness } \\ t & \text { Rehydration time }(\mathrm{h}) \\ \Delta E & \text { Total color change } \\ Q_{s} & \text { is the specific energy consumption in } \mathrm{kWh} / \mathrm{kg} \text { water } \\ Q_{t} & \text { is the consumed energy in } \mathrm{kWh} \\ m_{w} & \text { is the mass of vaporized water in } \mathrm{kg} \text { water } \\ R_{R} & \text { Rehydration ratio } \\ W_{t} & \text { Water content at a specific time (g water) } \\ W_{d r y} & \text { Dry weight of product }\end{array}$




\section{References}

Aamir M, Boonsupthip W (2017) Effect of Microwave Drying on Quality Kinetics of Okra. Journal of Food Science and Technology 54(5): 1239-1247.

Adom KK, Dzogbeüa VP, Ellis WO (1997) Combined Effect of Drying Time and Slice Thickness on the Solar Drying of Okra. Journal of Science and Food Agriculture 73(3): 315-320.

Afolabi TJ, Agarry SE (2014) Thin Layer Drying Kinetics and Modelling of Okra (Abelmoschus Esculentus (L.) Moench) Slices under Natural and Forced Convective Air Drying. Food Science and Quality Management 28(2014): 35-49.

Ajav E, Fakayode O (2011) Effect of Tray Loading Density on the Drying Characteristics of Okra. Tarım Makinaları Bilimi Dergisi 7(4): 333-337.

Al-Sulaiman MA (2011) Prediction of Quality Indices During Drying of Okra Pods in a Domestic Microwave Oven Using Artificial Neural Network Model. African Journal of Agricultural Research 6(12): 2680-2691.

AOAC - Official Method of Analysis (1990) Association of Official Analytical Chemists, Arlington, USA.

Başlar M, Kılıçlı M, Toker OS, Sağdıç O, Arici M (2014) Ultrasonic Vacuum Drying Technique as a Novel Process for Shortening the Drying Period for Beef and Chicken Meats. Innovative Food Science and Emerging Technologies 26(Dec): 182-190.

Cao ZZ, Zhou LY, Bi JF, Yi JY, Chen QQ, Wu XY, Zheng JK, Li SR (2016) Effect of Different Drying Technologies on Drying Characteristics and Quality of Red Pepper (Capsicum frutescens L.): A Comparative Study. Journal of Science and Food Agriculture 96(10): 3596-3603.

Dadalı G, Apar D, Ozbek B (2007) Microwave Drying Kinetics of Okra. Drying Technology 25(5): 917-924.

Doymaz I (2005) Drying Characteristics and Kinetics of Okra. Journal of Food Science and Engineering 69(3): 275-279.

Doymaz I (2011) Drying of Geen Bean and Okra Under Solar Energy. Chemical Industry \& Chemical Engineering Quarterly 17(2): 199-205.

El-Mesery HS, Mwithiga G (2012) Comparison of a Gas Fired Hot-Air Dryer with an Electrically Heated Hot-Air Dryer in terms of Drying Process, Energy Consumption and Quality of Dried Onion Slices. African Journal of Agricultural Research 7(31): 4440-4452.

Feng H, Tang J (1998) Microwave Finish Drying of Diced Apples in a Spouted Bed. Journal of Food Science 63(4): 679-683.

Gogus F, Maskan M (1999) Water Adsorption and Drying Characteristics of Okra. Drying Technology 17(4-5): 883-894.

Huang JP, Zhang M (2016) Effect of Three Drying Methods on the Drying Characteristics and Quality Of Okra. Drying Technology 34(8): 900-911.

Ismail MA, Ibn Idriss EM (2013) Mathematical Modelling of Thin Layer Solar Drying of Whole Okra (Abelmoschus esculentus (L.) Moench) Pods. International Food Research Journal 20(4): 1983-1989.

İsmail O, Kocabay OG (2016) Evaluation of the Drying Methods and Conditions with respect to Drying Kinetics, Colour Quality and Specific Energy Consumption of Thin Layer Pumpkins. Bulgarian Chemical Communications 48(3):480-491.

Kocabay OG, Ismail O (2017) Investigation of Rehydration Kinetics of Open-Sun Dried Okra Samples. Heat Mass Transfer 53(6): 2155-2163. 
Krokida MK, Philippopoulos C (2005) Rehydration of Dehydrated Foods. Drying Technology 23(4): 799-830.

Mana LV, Orikasab T, Muramatsuc Y, Tagawaa A (2012) Impact of Microwave Drying on the Quality Attributes of Okra Fruit. Journal of Food Processing and Technology 3(10): 186 doi:10.4172/2157-7110.1000186.

Moreira R, Chenlo F, Chaguri L, Fernandes C (2008) Water Absorption, Texture, and Color Kinetics of Air-Dried Chestnuts During Rehydration. Journal of Food Engineering 86(4): 584-594.

Motevali A, Minaei S, Khoshtagaza MH (2011) Evaluation of Energy Consumption in Different Drying Methods. Energy Conversion and Management 52(2): 11921199.

Okos M, Rao N, Drecher S, Rode M, Kozak J (1998) Energy Usage in the Food Industry, American Council for an Energy-Efficient Economy. Research Report IE981.

Okos MR, Campanella O, Narsimhan G, Singh RK, Weitnauer AC (2007) Food Dehydration. In DR Heldman, DB Lund (eds), Handbook of Food Engineering Food Dehydration. USA: CRC Press.

Pan Z, Khir R, Godfrey LD, Lewis R, Thompson JR, Salim A. (2008) Feasibility of Simultaneous Rough Rice Drying and Disinfestations by Infrared Radiation Heating and Rice Milling Quality. Journal of Food Engineering 84(3): 469-479.

Pendre NK, Nema PK, Sharma HP, Rathore SS, Kushwah SS (2012) Effect of Drying Temperature and Slice Size on Quality of Dried Okra (Abelmoschus esculentus (L.) Moench). Journal of Food Science and Technology 49(3): 378-81.

Phoungchandang S, Saentaweesuk S (2011) Effect of Two Stage, Tray and Heat Pump Assisted-Dehumidified Drying on Drying Characteristics and Qualities of Dried Ginger. Food and Bioproducts Processing 89(4): 429-437.

Rudra SG, Singh H, Basu S, Shivhar US (2008) Enthalpy Entropy Compensation during Thermal Degradation of Chlorophyll in Mint and Coriander Puree. Journal of Food Engineering 86(3): 379-387.

Sakai N, Mao W (2006) Infrared Heating. In DW Sun (ed), Thermal Food Processing New Technologies and Quality Issues. USA: CRC Press.

Sharma GP, Prasad S (2006) Specific Energy Consumption in Microwave Drying of Garlic Cloves. EconPapers 31(12): 1921-1926.

Shivharea US, Gupta A, Bawa AS, Gupta P (2010) Drying Characteristics and Product Quality of Okra. Drying Technology 18(1-2): 409-419.

Tunde-Akintunde TY (2011) Mathematical Modelling of Sun and Solar Drying of Chilli Pepper. Renewable Energy 36(8): 2139-2145.

Wankhade PK, Sapkal RS, Sapkal VS (2012) Drying Characteristics of Okra Slices Using Different Drying Methods by Comparative Evaluation. Proceedings of the World Congress on Engineering and Computer Science 2012, vol II WCECS 2012, October 24-26, 2012, San Francisco, USA. 